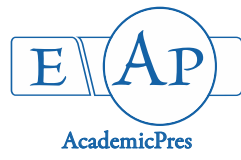

\title{
Genus Ophioglossum L., from Western Part of India with Special Reference to Gujarat State
}

\author{
Ronak N. KACHHIYAPATEL ${ }^{1}$, Sachin M. PATIL ${ }^{1}$, Suresh K. PATEL ${ }^{2}$, \\ Kishore S. RAJPUT ${ }^{1 *}$

\begin{abstract}
${ }^{1}$ The Maharaja Sayajirao University of Baroda, Faculty of Science, Department of Botany, Vadodara - 390002,
India; rkapatel7622.rk@gmail.com; sach2010d@gmail.com;ks.rajput15@yahoo.com ("corresponding author)
\end{abstract} \\ ${ }^{2}$ Government Science College Idar, Department of Botany, Dist.Banaskantha, Gujarat, India; sk_8003@yahoo.com
}

\begin{abstract}
The genus Ophioglossum L. is revised for the Gujarat state and there were reported eight species viz. Ophioglossum costatum R. Br., O. gramineum Willd., O. gujaratense SM Patil, RN Kachhiyapatel, R Patel and KS Rajput, $O$. lusitanicum L., $O$. reticulatum L., $O$. parvifolium Grev. \& Hook., $O$. nudicaule L. f. and $O$. thermale Kom., from different parts of the state. Amongst these, Ophioglossum thermale Kom. and O. lusitanicum L. were collected for the first time from Jambughoda Wildlife Sanctuary and this result is documented as a new distributional record for Gujarat state.
\end{abstract}

Keywords: eusporangiate; Gujarat state; Jambughoda wildlife sanctuary; pteridophytes

\section{Introduction}

Ophioglossum L. is a cosmopolitan genus of eusporangiate family Ophioglossaceae, which is mainly distributed in tropical and subtropics region of the world. About 45 species are reported from different region of the world, of which 13 species are reported from India (Patil and Dongare, 2014; Fraser-Jenkins et al., 2017). Among these species, Ophioglossum eliminatum Khand. and Goswami and O. indicum B. L. Yadav and Goswami are endemic to India (Khandelwal and Goswami, 1984; Yadav and Goswami, 2010). Pteridophyte diversity including the taxonomy of genus Ophioglossum L., from Gujarat is poorly studied. About six species viz. Ophioglossum costatum R. Br., (O. fibrosum Schumach.), O. gramineum Willd., $O$. nudicaule L.f., $O$. reticulatum L., $O$. valgatum L. and $O$. nudicaule var. macrorrbizum (Kunze) R.T. Clausen were reported by Phatak et al. (1953), Chavan and Mehta (1956), Inamdar and Shah (1967), Panighrahi and Dixit (1969), Inamdar (1970) and Dixit (1984) and one unidentified species (most probably Ophioglossum costatum because its wide occurrence in Gujarat. However, recently Kachhiyapatel et al. (2015) and Rajput et al. (2016a, b) revised the pteridophytes flora of Gujarat state and confirmed 05 species viz. Ophioglossum costatum R. Br., $O$. gramineum Willd., O. nudicaule L. f., $O$. parvifolium Grev. $\&$ Hook. and $O$. reticulatum L., for state (excluding dubious species). Recently, Patil et al. (2018) published a new species of Ophioglossum, Ophioglossum gujaratense from Gujarat.

During the study of genus Ophioglossum from different regions including forest areas of Gujarat authors have collected an interesting population of Ophioglossum L. from Jambughoda wild life sanctuary and its adjoining areas which is identified as Ophioglossum lusitanicum L. and $O$. thermale Kom. Therefore, both the species stand as new distribution records for Gujarat state.

\section{Materials and Methods}

Field studies were carried out regularly to different regions of the state including forest areas to collect the species of Ophioglossum L. The collected plant materials were processed under laboratory for the preparation of herbarium specimens. The specimens were identified with the help of relevant literature (Panigrahi and Dixit, 1969; Manickam and Irudayaraj, 1992; Patil, 2014; Fraser-Jenkins et al., 2017). Voucher specimens were deposited in BARO herbarium of the Department of Botany, The Maharaja Sayajirao University of Baroda, Vadodara (Gujarat).

\section{Results}

About eight species viz. Ophioglossum costatum R. Br., $O$. gramineum Willd., O. gujaratense SM Patil, RN Kachhiyapatel, R Patel and KS Rajput, $O$. lusitanicum L., $O$. reticulatum L., O. parvifolium Grev. \& Hook., O. nudicaule 
374

L. f. and $O$. thermale Kom. were collected from different regions of Gujarat State. Amongst these, O. lusitanicum L., and $O$. thermale Kom. were reported as new distributional record for Gujarat state. All these species are growing luxuriantly with more than 200-300 individuals per locality. Along with key to species of Gujarat state, detailed description, distribution, ecology and conservation of each species is given herewith for its easy identification.

Key to species of Ophioglossum from Gujarat

1a. Sheathing leaf base present ............ O. gujaratense

1b. Sheathing leaf base absent ................................. 2

2a. Rhizomorph globose............................... O. costatum

2b.Rhizomorph globose-subglobose .......................... 3

3a. Trophophylls linear-lanceolate .............................. 4

3b. Trophophylls not linear-lanceolate ....................... 5

4a. Trophophylls stalked, grass like ......... gramineum

4b. Trophophylls neither stalked, nor grass like ... $O$. lusitanicum

5a. Trophophylls more than 2 per rhizomorph ...... 6

5b. Trophophyll only one per rhizomorph 6 reticulatum

6a. Common stalk strictly subterranean ......... $O$. parvifolium

6b. Common stalk present subterranean-above the ground ... 7

7a. Trophophylls elliptic-ovate or oblong $O$. nudicaule

7b. Trophophylls elliptic-lanceolate O. thermal

Ophioglossum costatum R. Br., Prod. Fl. Nov. Holl. 163. 1810. Panigrahi and Dixit, Proc. Nat. Inst. Sci. India 35: 249. 1969; Patil and Dongare, Indian Fern J., 31: 17-24. 2014. (Fig. 1 A,E)

Type: Australia, Queensland, Arnhem North Bay, Brown 118.

Ophioglossum pedunculosum Desv., Mag. Nat. Fr. Berlin 5: 306.1811 .

Ophioglossum brevipe Bedd., Ferns. Southern India 23. t. 72. 1863.

Plants have more than $10 \mathrm{~cm}$, pale-green, terrestrial, herb; rhizomorph disc like or globose, bearing numerous yellow-brown, fleshy, without stoloniferous roots; common stalk 2-3 cm, base white, apex pale green; trophophylls 1-4 simple, erect, elliptic-lanceolate, ovate-round or spathulate, apex acute-apiculate or obtuse-round, base cuneate-cordate, margin entire, thick fleshy, green when fresh, glabrous on both sides, coriaceous, midrib prominent; fertile segment grooved, unbranched, inserted on adaxial position of leaf; strobili 20-35 sporangia in two alternate rows, pale yellow, unbranched (rarely branched); spores $20-40 \mu \mathrm{m}$ in diameter, trilete, feveolate.

Distribution: World: India, Bangladesh, Indonesia, Malaysia, Philippines, Sri Lanka, Thailand, Africa and Australia.

India: Throughout

Gujarat: Throughout Gujarat state

Phenology: sterile phase -June-August; fertile phase: July (end)-September (rarely in October).
Ecology: Very common, collected from grassy plateau. The population of the plants varies according to the water content of the soils.

Conservation status: Ophioglossum costatum $\mathrm{R}$. Br. is collected from throughout Gujarat state. A population of about 300-400 individuals per $\mathrm{km}^{2}$ were found and the area of occupancy (AOO) is $100-200 \mathrm{~km}^{2}$. Therefore, as per IUCN categories and criteria (IUCN ver. 2017-1), it is assessed as least concerned (LR) species for Gujarat state.

Specimen examined: INDIA-TAMIL NADU, Tirunelveli, way to Thulukkamparair, alt. $300 \mathrm{~m}$, 06/09/1969, B. V. Shetty (MH62410); Tiruchirappalli, Narthamalai, alt. 333 m, 12/09/1958, K. Sulenamanyaml (MH17577); KERALA-Idukki Dt., Pindimedu Pooyamkutty, Bhargavan (MH87404).

Ophioglossum gramineum Willd. Nov. Act. Acad. Erfurt. 2: 18. t. f. 1 (1802); Beddome, Handb. Suppl. Ferns Brit. India 108. 1892; Balakrishnan et al., Bull. Bot. Surv. India 2: 337 (1960); Panigrahi \& Dixit, Proc. Nat. Inst. Sci. India 35: 250 (1969); Patil and Dongare, Indian Fern Journal 31:17-24. 2014.(Fig. 1 B, F)

Type: West Africa, St. Thomae, De Friedland B.

Ophioglossum clietrichiae Prantl, Ber. Deut. Bot. Ges. 1: 352 (1883)

Plants are terrestrial herbs, $2-4 \mathrm{~cm}$ long; rhizomorph subglobose-tuberous, subterranean, with fleshy roots; common stalk terranean, white-green; trophophylls 1-2, linear grass-like, apex acuminate, margin entire; veins anastomosing, forming parallel areoles; fertile segment pale green, flat-round, arising from the base of the sterile blade; strobili 5-8 pairs of sporangia, arranged in two alternate rows, pale green-yellow; spores $25-40 \mu \mathrm{m}$ diam, trilete, exine reticulate.

Distribution: World - India, Indonesia, Malaysia, Myanmar, Philippense, East Borneo, East Java, New Guinea, Vietnam, Africa and Sri Lanka.

India: Throughout

Gujarat: Throughout

Phenology: sterile phase -June-August; fertile phase: July (end)-September (rarely in October)

Ecology: Common fern collected from grassy plateaus associated with $O$. nudicaule, $O$. petiolatum and $O$. costatum.

Conservation status: Ophioglossum gramineum Willd. is collected from open grassland habitats situated in Gujarat state. A population of about more than 2,000 individuals was found. The area of occupancy (AOO) is $200-300 \mathrm{~km}^{2}$. Therefore, as per IUCN categories and criteria (IUCN ver. 2017-1), it is assessed as least concerned (LR) species for Gujarat state.

Specimen examined: INDIA - MAHARASHTRA: Kolhapur Dt., Shivaji University, campus, alt. 700 m., Patil S. S. (SUK); KARNATAKA: Belgaum Dt., Adi, alt. 800 m, Mahamuni R. J. (SUK); ANDHRA PRADESH: Karimnagar Dt., Aklaspur, Subbarao (MH20238).

Ophioglossum gujaratense SM Patil, RN Kachhiyapatel, R Patel, KS Rajput, Phytotaxa 351(4):273-280 (Fig. 1K, O). Type: India, Gujarat, Panchmahal dt, Dhanpuri. 
Plants herbaceous, less than $10 \mathrm{~cm}$, terrestrial; rbizomorph subterranean, sub-globose when young and tuberose on maturity, yellow-brown, with numerous fleshy roots; common stalk $0.5-1.5 \mathrm{~cm}$ long, subterranean, white, glabrous, covered with leaf sheath (brown or white); common stalk subterranean, white, covered with brownwhite leaf sheath: trophophylls horizontal, touching to the ground, slightly convex from above, $0.5-2 \mathrm{~cm}$ long, $0.5-1.2$ $\mathrm{cm}$ broad, $1-5$ per rhizomorph, ovate-elliptic or ellipticlanceolate, apex acute-acuminate and cuneate at base, margins entire, glabrous, tough, horizontally attached to substratum; fertile segment $2-8 \mathrm{~cm}$ long, round-flat, pale green-green, arising from base of leaf; strobili $0.5-2 \mathrm{~cm}$ long, apex acute-acuminate, green (young)-yellow (mature); sporangia 5-15, arranged in two alternate rows; spores trilete, exine verrucose, measuring $30-40 \mu \mathrm{m}$ in diameter.

Distribution: India

India: Gujarat

Gujarat: Dhanpuri, Zand Hanuman, Shivrajpur

Phenology: sterile phase June-July; fertile phase: AugustSeptember

Ecology: The species is growing on hill slopes at 200-300 $\mathrm{m}$ asl, associated with Ophioglossum costatum, $O$. parvifolium and $O$. reticulatum.

Conservation status: Ophioglossum gujaratense is collected from a grassy hill slopes and flat land. A population of about 500-700 individuals $/ \mathrm{km}^{2}$ was found at each locality. Furthermore, we assume that the species might be dispersed in similar ecological conditions. Hence, more floristic explorations are needed to define and document the full range of distribution of $O$. gujaratense. Therefore, according to IUCN (2017 ver.-1) criteria, at present this species is considered as data deficient (DD).

Specimen examined: India - Gujarat, Panchmahal district, Jambughoda, Dhanpuri, $22^{\circ} 21.486^{\prime} \mathrm{N} 73^{\circ} 42.871^{\prime} \mathrm{E}$, $124 \mathrm{~m}, 30^{\text {th }}$ July 2017, S.M. Patil, R.N. Kachhiyapatel \& K.S.Rajput 215 (BARO) BARO0070041.

Ophioglossum lusitanicum L. sp. Pl., 2:1063, 1753; Clausen, Mem. Torry Bot. Club 19(2):159, 1938; Mahable, Bull. Bot. Surv. India 4:71, 1962; Panigrahi \& Dixit, Proc. Nat. Inst. Sci. India 35: 251, 1969; Patil \& Dongare, Indian Fern Journal 31:17-24, 2014 (Fig. 1 D, H).

Type: Portugal, "Habitat in Lusitania", not designated.

Plant small, terrestrial herb; rbizomorph subterranean, subglobose-tuberous without stoloniferous fleshy roots; common stalk subterranean, white-brownish green; trophophylls 1-2, erect, red-brown-green, spathulate, linearlanceolate or elliptic-lanceolate, acute-acuminate apex, cuneate-attenuate base, entire margin; venation simple reticulate; fertile segment round, unbranched, green-yellow brown; strobili 8-12 sporangia in two rows; spores 20-25 $\mu \mathrm{m}$ diam, trilete, exine reticulate.

Distribution: World - India, Algeria, Morocco, Portugal (Azores), Spain (Canary Is.), Tanzania, United Republic of Tunisia; Uganda

India: Andhra Pradesh, Assam, Bihar, Goa, JammuKashmir, Karnataka, Kerala, Madhya Pradesh, Maharashtra, Orissa, Punjab, Tamil Nadu, Uttar Pradesh,
West Bengal.

Gujarat: Jambughoda, Zand Hanuman

Phenology: sterile phase June-August; fertile phase: July (end)-August (rarely September)

Ecology: Uncommon species, collected from grassy plateaus at Jambughoda and Zand Hanuman, associated with $O$. costatum, $O$. nudicaule, $O$. parvifolium and $O$. reticulatum.

Conservation status: Ophioglossum lusitanicum L. is collected from plateaus of Jambhughoda and Zand Hanuman. A population of about more than 100-200 individuals was found. However, the area is poorly explored for the Ophioglossum lusitanicum. Therefore, it was assumed that the other population might be distributed around this area and more floristic explorations are needed to determine its full range distribution. At present the species should be considered as Data Deficient for now.

Specimen examined: India - Kerala, Trivandrum, forest between Thura and Bonasoore, alt. $525 \mathrm{~m}$, J. Joseph (MH90512); Maharashtra, Kolhapur dt. near Doodhsagar Dam, Radhanagari, 10/09/2013. SMP (2002).

Ophioglossum nudicaule L. f. Suppl. Pl. Syst. 443 (1781); Beddome, Handb. Ferns Br. India, 464, t. 228 (1883); Panigrahi \& Dixit, Proc. Nat. Inst. Sci. India 35. 252 (1969); Beddome Handb. 106 (1974); R.D. Dixit, Cens. Ind. Pterid. 23 (1984); Manickam \& Irudayaraj, Pterid. Fl. West Ghats: 48-49. t. 27 (1992) (Fig. 1 L, P).

Type - South Africa, Cape of Good Hope.

Ophioglossum capense Sw., Schard. Journ. 1801(2): 308 (1803).

Ophioglossum ellipticum Hook. \& Grev.Icon. Filic. t. 40 A (1828).

Ophioglossum lineare Schlechter et Brause, Bot. Jerb., 49: 59, fig. 3F (1912).

Ophioglossum luersseni Prantl, Ber. deut. Bot. Ger. 1: 352 (1883).

Plant terrestrial, $4-8 \mathrm{~cm}$ height; rhizomorph subglobose, bearing many soft fibrous roots; common stalk $0.5-1.5 \mathrm{~cm}$, terranean, white-green; trophophylls 1-2 (rarely 3), 0.5-2 x 1$2 \mathrm{~cm}$, green, touft ovate or elliptic, apex obtuse, base cuneate; veins reticulate, with free veinlets at margins; fertile segment 2-6 $\mathrm{cm} \times 0.1-0.4 \mathrm{~mm}$ broad, green at young, yellow at maturity; strobili $1.5-2.5 \mathrm{~cm}$ long, with $10-20$ sporangia per strobilus; spores 30-40 $\mu \mathrm{m}$ diam, trilate, with reticulate ornamentation.

Distribution: World - India, China, Indonesia; Malaysia; Thailand

India: Andhra Pradesh, Himachal Pradesh, JammuKashmir, Gujarat, Jharkhand, Karnataka, Kerala, Maharashtra, Sikkim, Tamil Nadu, West Bengal.

Gujarat: Jambughoda, Zand Hanuman, Dang forest, Vansda, Waghai, Mahal, Don.

Phenology: sterile phase - June-August; fertile phase: August-September.

Ecology: Very common species grows in patches on fully exposed localities of open grassland associated with Ophioglossum costatum, O. gramineum, $O$. parvifolium, $O$. thermale and $O$. reticulatum. 
376

Conservation status: Ophioglossum nudicaule L. f. is collected from open grasslands of Gujarat State of India. A population of about 200-400 individuals are found. The area of occupancy (AOO) is $100-200 \mathrm{~km}^{2}$. Therefore, as per IUCN categories and criteria (IUCN ver. 2017-1), it is assessed as least concerned (LR) species for Gujarat state.

Specimen examined: INDIA - Madhya Pradesh, Hoshangabad Dist. Kesla, alt. 500 m, 22/07/1961, J. Joseph (MH25305); Tamil Nadu, Ramnad Dist., Erani forest, alt. 100 m., 19/08/1964, R. D. Dixit (MH39459).

Ophioglossum parvifolium Grev. \& Hook. Bot. Misc. 3: 218, 1833; Patil and Dongare, Indian Fern Journal 31:1724. 2014. (Fig. 1 J, N).

Type: India, Negapatam, Tamil Nadu.

$O$. nudicaule var. macrorrhizum (Kunze) Clausen, mem. Torrey Bot. Club, 19 (2): 150, 1938.

Plant less than $10 \mathrm{~cm}$, terrestrial herbs; rhizomorph subterranean, subglobose-tuberous, bearing few fertile and sterile leaves at the apex; common stalk subterranean, white, glabrous; trophophylls 1-2, ovate-lanceolate, apex acuteapiculate, margin entire, base cordate; veins simple reticulate, four or five veins passing up through the stalk of the blade; fertile segment $2-4 \mathrm{~cm}$ long, round, pale greengreen; strobili $0.5-1 \mathrm{~cm}$ long, 5-10 sporangia, arranged in two alternate rows; spores $25-45 \mu \mathrm{m}$ diam, trilete, exine reticulate.

Distribution: World - India, China, South America, Sumatra, Malaysia, Thailand.

India: Madhya Pradesh, Gujarat, Maharashtra, Karnataka, Rajasthan, Kerala, Tamil Nadu.

Gujarat: Throughout (except Kutchh region).

Phenology: sterile phase - June-August; fertile phase: July (end)-September

Ecology: Very common species grows in patches on fully exposed areas from low land to high land areas.

Conservation status: Ophioglossum parvifolium Grev. \& Hook., is collected from different regions of Gujarat state (excluding Kutchh). A population of about 1,500-2,000 individuals were found. The area of occupancy (AOO) is $100-200 \mathrm{~km}^{2}$. Therefore, as per IUCN categories and criteria (IUCN ver. 2017-1), it is assessed as least concerned (LR) species for Gujarat state.

Specimen examined: India - Maharashtra, Kolhapur Dt. Near Radhanagri Dam, 10/09/2013. SMP (2002); Maharashtra, Satara Dt. Kas Platue, 05/08/2014. SMP (2003).

Ophioglossum reticulatum L. Sp. Pl. 2: 1063 (1753); Beddome, Ferns. Southern India 23. t. 70. 1863; Beddome, Handb. Ferns. Bri. India, 465. t. 290 (1883); Panigrahi \& Dixit, Proc. Nat. Inst. Sci. India 35. 257 (1969); Bedd., Handb. 107. 1974; R.D. Dixit, Cens. Ind. Pterid. 24 (1984); Manickam \& Irudayaraj, Pterid. Fl. West Ghats: 51. t. 29 (1992); Patil and Dongare, Indian Fern Journal 31:1724. 2014. (Fig. 1 I, M)

Type - Mauritius. 1845 .

Ophioglossum peruvianum Presl, Suppl. Tent. Pterid 52.

Ophioglossum petiolatum sensu Wieffering, Blumea, 12: 327. 1964.
Ophioglossum cordifolium Roxb., Hort. Bengal, 75. 1814;

Plant terrestrial, 10-25 cm long; rhizomorph 3-7 mm long, tuberous, bearing few long, thick fleshy unbranched roots, with 1-2 trophophylls; common stalk $2-5 \mathrm{~cm}$, terranean, white at base, green above; trophophylls 1 (rarely 2), $8-15 \mathrm{~cm}$ long, subterranean, cordate, broadly ovate, rarely elliptic-oblong or broadly ovate, apex rounded, base cordate to broadly cuneate; veins reticulate, several lateral veins passing to the base of the blade, the ultimate areoles with or without included free veinlets; fertile segment 12-17 $\mathrm{cm}$. long, linear, lanceolate; strobili $0.5-1.5 \mathrm{~mm}, 20-25$ pairs of sporangia, globose, sunken sporangia arranged in two alternate compact rows; spores $30-45 \mu \mathrm{m}$ dia., spherical, trilete, exine hemispherical.

Distribution: World - India, Malay Peninsula, Tropical America, Africa, Philippines and Sri Lanka.

India - Andhra Pradesh, Gujarat, Kerala, Karnataka, Maharashtra, Madhya Pradesh, Panjab, Tamil Nadu, West Bengal.

Gujarat: Throughout the state (excluding Kutchh).

Phenology: sterile phase - June-August; fertile phase: August-October.

Ecology: Very common, found under beneath of trees in the forest or grassy plateaus along with Ophioglossum costatum, O. gramineum, $O$. nudicaule, $O$. lusitanicum and O. parvifolium.

Conservation status: Ophioglossum reticulatum L., is collected from open grasslands of Gujarat state. A population of about 500-600 individuals are found. The area of occupancy (AOO) is $100-200 \mathrm{~km}^{2}$. Therefore, as per IUCN categories and criteria (IUCN ver. 2017-1), it is assessed as least concerned (LR) species for Gujarat state.

Specimen examined: India - Tamil Nadu, Tirunelveli, near Kanni forest rest house, alt. 800 m, 28/08/1963, A. N. Henry (MH39280); Courtallum, Barber (MH). Tiruchirappalli Dt., Lalgudi, Kondaiampatti, Subramanyan (MH7780).

Ophioglossum thermale Kom., Repert. Spec. Nov. Regni Veg. 13: 85. 1914; Panigrahi \& Dixit, Proc. Nat. Inst. Sci. India 35. 257 (1969); R.D. Dixit, Cens. Ind. Pterid. 24 (1984). (Fig. 1 C, G).

Type - Russia, Kamtchatka.

Ophioglossum angustatum Maxon, Proc. Biol. Soc. Washington 36:169. 1923.

O. japonicum Prantl., Ber. Deutsch. Bot. Ges.1: 353. 1883.

Plants terrestrial, $8-15 \mathrm{~cm}$ tall; rhizomorph $0.2-04 \mathrm{~mm}$, tuberose, bearing a tuft of unbranched fleshy roots, stoloniferous; common stalk $1-4 \mathrm{~cm}$, terranean, white at base, pale green above; trophophylls 1-2 x 0.2-0.7 cm, 1 (rarely 2), simple, sessile, brown at young, light green-pale green at maturity, oblanceolate-oblong, herbaceous, apex acute, base cuneate, margin entire; veins reticulate, indistinct; fertile segment 5-9 cm, pale green, linear lanceolate; strobili $2-3 \mathrm{~cm} \times 0.1-0.2 \mathrm{~cm}$, linear, acute at apex, with 10-18 pairs of sporangia; spores $30-40 \mu \mathrm{m}$ dia., pale, sub-reticulate.

Distribution: World - India, China, Korea, Japan. 
India - Gujarat, Maharashtra.

Gujarat: Jambughoda, Zand Hanuman.

Phenology: sterile phase - June-August; fertile phase: August-September (rarely in October).

Ecology: Uncommon species, found under beneath of trees in the forest or grassy plateaus along with Ophioglossum costatum, O. gramineum, O. nudicaule, O. lusitanicum and O. parvifolium.

Conservation status: Ophioglossum thermale Kom., is collected from grassy plateaus of Jambhughoda and Zand Hanuman. A population of about more than $200-400$ individuals was found. However, the area is poorly explored for the $O$. thermale. Therefore, an assumption that the other population might be distributed around this area and more floristic explorations are needed to determine its full range distribution, the species should be considered as Data Deficient for now.

Specimen examined: INDIA - Gujarat, Panchmahal district, Jambughoda, Dhanpuri, $22^{\circ} 21.61^{\prime} \mathrm{N}, 73^{\circ} 42.81 \mathrm{E}^{\prime}$, $128 \mathrm{~m}, 18^{\text {th }}$ Aug 2014, S.M.Patil, R.N.Kachhiyapatel \& K.S.Rajput 27, 28 (BARO) BARO 123450070029.

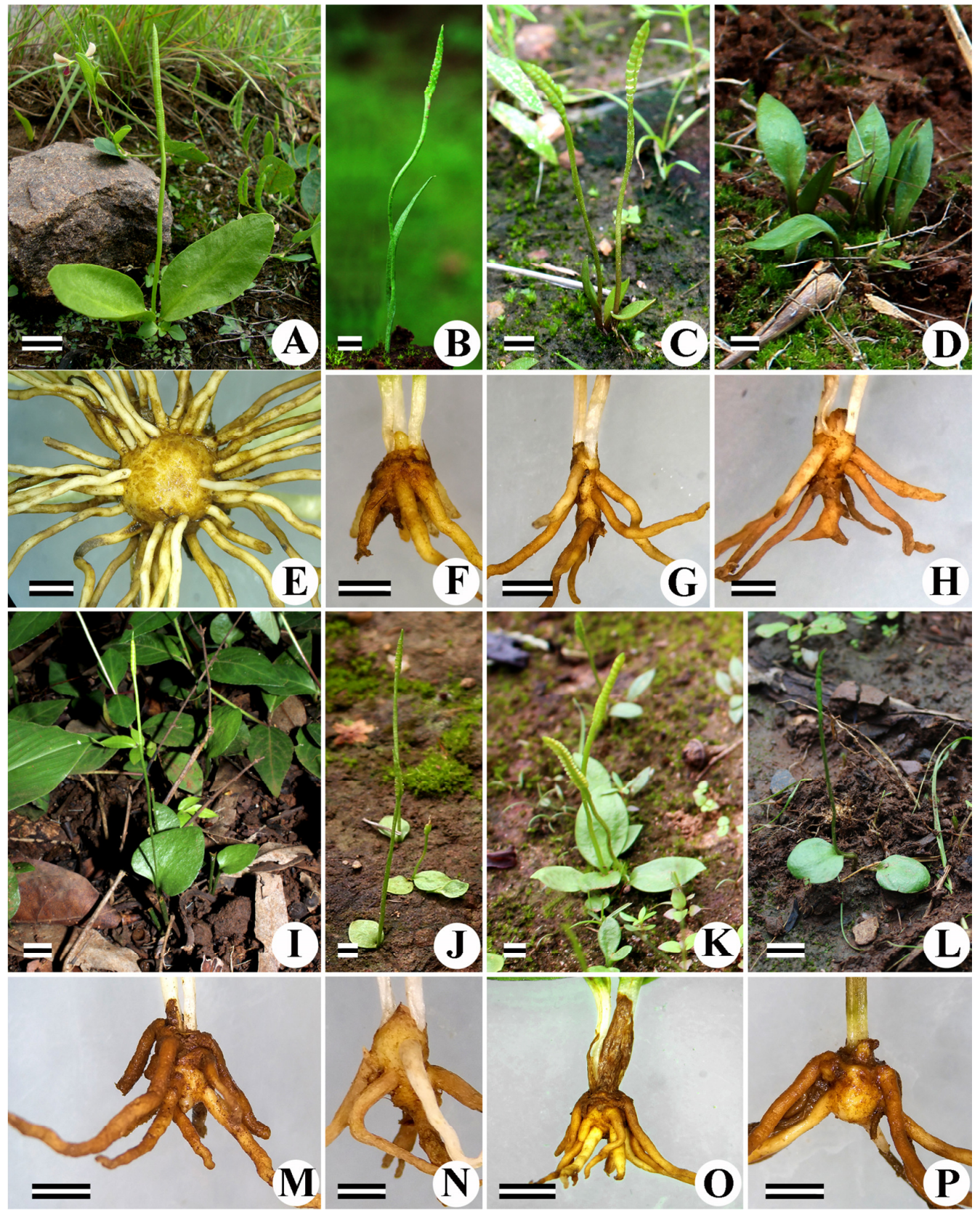

Fig. 1. A-D: Habit of Ophioglossum costatum, O. gramineum, O. thermale and O. lusitanicum, F-H: Rhizome of O. costatum, O. gramineum, O. thermale, O. lusitanicum respectively, I-L: Habit of $O$. reticulatum, O. parvifolium, O. gujaratense, O. nudicaule, M-P: Rhizome of $O$. reticulatum, O. parvifolium, O. gujaratens, O. nudicaule respectively. Scale bar: A, I, L: 10 mm, B-H, J,K, M-P: 5 mm. 
378

\section{Discussion}

Recently, Fraser-Jenkins et al. (2017) published "An Annotated checklist of India pteridophytes - I' and reported 12 species of Ophioglossum in India. He mentioned that $O$. thermale Kom., has been reported by Indian authors in error for O. lancifolium C. Presl. However, The Ophioglossum lancifolium is more than $15 \mathrm{~cm}$ without stoloniferous roots, common stalk more than $4 \mathrm{~cm}$ above the ground; trophophylls acute to apiculate, elliptic-oblanceolate. Nevertheless, presence of stoloniferous roots, subterraneanto-above the ground, less than $4 \mathrm{~cm}$ common stalk, acuteround, elliptic-lanceolate trophophylls that differentiate $O$. thermale from $O$. lancifolium. Thus, present paper reports $O$. thermale, which is present in India and reported as new distributional record for Gujarat state whereas, occurrence of $O$. lancifolium in India is doubtful and need to explore for conformation. Similarly, O. lusitanicum is also reported as a new distributional record for Gujarat state. O. lusitanicum can be separated from $O$. gramineum, $O$. thermale and $O$. lancifolium by linear-lanceolate trophophylls that are not grass like and lacking above ground stalk. The most common species in Gujarat are Ophioglossum costatum, $O$. gramineum, $O$. nudicaule, $O$. parvifolium and $O$. reticulatum.

\section{Conclusions}

The present study documents occurrence of $O$. thermale and $O$. lusitanicum as a new distribution record from Gujarat. Though there is a controversy about occurrence of $O$. thermale in India; however, the presence of stoloniferous roots and subterranean-to-above the ground, acute-round, elliptic-lanceolate trophophylls with a common stalk differentiate this species from closely related taxa $O$. lancifolium. These entire features are shared by specimens collected from Gujarat. Recently, Patel and Reddy (2018) misidentified Ophioglossum lusitanicum (for juvenile $O$. thermale) and $O$. thermale (for juvenile $O$. reticulatum or $O$. costatum) from Gujarat state. Thus, the present paper deals with correct identification of Ophioglossum lusitanicum and $O$. thermale from Gujarat state.

\section{Acknowledgements}

The present work is supported to one of the authors (SMP) by Science and Engineering Research Board (SERB) for financial support under NPDF programme. Authors are thankful to Gujarat Biodiversity Board (GBB) and Department of Forest, Govt. of Gujarat for the necessary permissions to visit the forest areas. Thank are also due to the Editor and anonymous reviewers for their valuable suggestions on the previous version of the manuscript.

\section{References}

Chavan AR, Mehta AR (1956). Occurrence of Ophioglossum gramineum Willd in Gujarat. Science and Culture 21:538-540.
Dixit RD (1984). A census of the Indian Pteridophytes. Flora of India, Ser.4. Botanical Survey of India, Howrah (Calcutta), India.

Fraser-Jenkins CR, Gandhi KN, Kholia BS Benniamin A (2017). An annotated checklist of Indian Pteridophytes Part-1 (Lycopodiaceae to Thelypteridaceae). Messrs Bishen Singh Mahendra Pal Singh.

InamdarJA, Shah JJ (1967). Occurrence of Ophioglossum nudicaule L.f. and Ophioglossum nudicaule var. macrorrbizum (Kze.) Clausen in Dharampur Forest. Indian Forester 93(2):95-97.

InamdarJA (1970). Development of stomata in some Ophioglossum species. Annals of Botany 34:975-981.

IUCN (2017). The IUCN Red List of Threatened Species Version 2017-1.

Kachhiyapatel RN, Singh AP, Raole VM, Rajput KS (2015). Distribution and occurrence of some pteridophytes in Gujarat state: A new record for the state. Journal of the Indian Botanical Society 94(3-4):236-244.

Khandelwal S, Goswami HK (1984). A new Ophioglossum from India. The Fern Gazette 12:330.

Manickam VS, Irudayaraj V (1992). Pteridophyte flora of south India. Today and Tomorrow's Publications, New Delhi.

Panigrahi G, Dixit RD (1969). Studies in Indian Pteridophytes-IV. The family Ophioglossaceae. India. Proceedings of the National Academy of Sciences, India. 35B:230-266.

Patel M, Reddy MN (2018). Additions to the Pteridophyte diversity of Gujarat, India. International Journal of BotanyStudies3(2):164167.

Patil S (2014). Systematic studies on pteridophytes of Satara districts (Maharastra). Ph.D. Thesis submitted to Shivaji University, Kolhapur, (MaharashtraState, India).

Patil S, Dongare M(2014). The genus Ophioglossum from Western Ghats of India. Indian Fern Journal 31:17-24.

Patil SM, Kachhiyapatel RN, Patel RS, Rajput KS (2018). Ophioglossum gujaratense, a new species from Gujarat State, India. Phytotaxa 351(4):273-280.

Phatak VG, Gaekwad, LK, Deshmukh, YS (1953). Ophioglossum from Baroda and teratology. Journal of the M.S. University of Baroda 2(2):135-141.

Rajput KS, Kanchhiyapatel RN, Raole VM, Singh AP (2016a). Relocation of Ophioglossum gramineum Willd (Ophioglossaceae). Current Science 111(2):243.

Rajput KS, Kachhiyapatel RN, Patel SK, Raole VM (2016b). Study on Pteridophyte diversity of Gujarat state, Western India. Plant Science Today 3(4):327-338.

Yadav BL, Goswami HK (2010). A new, pink-brown Ophioglossum (Ophioglossaceae) from India. Bulletin of the National Museum of Nature and ScienceSeries B 36(4):155-159. 